\title{
Anemia and Its Determinants among Male and Female Adolescents in Southern Ethiopia: A Comparative Cross-Sectional Study
}

\author{
Melat Belay Zeleke, Mohammed Feyisso Shaka ${ }^{\mathbb{D}}$, Adane Tesfaye Anbesse, \\ and Solomon Hailemariam Tesfaye
}

School of Public Health, College of Health Sciences and Medicine, Dilla University, Dilla, Ethiopia

Correspondence should be addressed to Mohammed Feyisso Shaka; mamfys8@gmail.com

Received 24 March 2020; Revised 31 August 2020; Accepted 19 September 2020; Published 9 October 2020

Academic Editor: Duran Canatan

Copyright (c) 2020 Melat Belay Zeleke et al. This is an open access article distributed under the Creative Commons Attribution License, which permits unrestricted use, distribution, and reproduction in any medium, provided the original work is properly cited.

\begin{abstract}
Background. Adolescent anemia is a major public health problem worldwide. Adolescents (10-19 years) are at an increased risk of developing anemia due to increased iron demand during puberty, menstrual losses, limited dietary iron intake, and faulty dietary habits. Objective. To assess the prevalence of anemia and associated factors among male and female adolescent students in Dilla Town, Gedeo Zone, Southern Ethiopia, May 2018. Methods. A school-based comparative cross-sectional study was employed among 742 school adolescents. Basic characteristics, anthropometric measurements, haemoglobin measurement, and others were collected. Data were analyzed using SPSS version 20 software, and descriptive statistics were computed for all variables. Bivariate and multivariable logistic regression analyses using binary logistic regression were done, the results were interpreted by using AOR with their corresponding 95\% CI, and statistically significant difference was declared at $p<0.05$ Result. Out of the total 742 respondents, $377(50.8 \%)$ were males and $365(49.2 \%)$ were females. The overall prevalence of anemia was $21.1 \%$, and the prevalence of anemia was $22.5 \%$ among male adolescents and $19.7 \%$ among females. Male adolescent students within the early adolescence age group (10-13 yrs) (AOR $0.27,95 \% \mathrm{CI}, 0.08-0.87$ ), those consuming fibre-rich foods daily (AOR $0.11,95 \% \mathrm{CI}$, 0.02-0.61), and those having no intestinal parasites (AOR 0.04, 95\% CI, 0.02-0.09) were less likely to be anemic. Similarly, female adolescent students not having intestinal parasites (AOR 0.05, 95\% CI, 0.01-0.11) were less likely to develop anemia while those from malaria endemic area (AOR 2.57, 95\% CI, 1.13-5.83) were identified to be more anemic. Conclusion. This study identified that anemia was a moderate public health significance in the study area, and the prevalence of anemia was slightly higher among male than female adolescents. Age category, frequency of eating fibre-rich foods, and positive intestinal parasite tests were factors contributing for anemia among male adolescents while presence of intestinal parasite and malaria endemicity were the determinants of anemia among female adolescents.
\end{abstract}

\section{Background}

Anemia is defined as a decrease in the concentration of circulating red blood cells or haemoglobin concentration resulting in insufficient oxygen carrying capacity of red blood cells to meet the physiological needs of the body $[1,2]$. Anemia generally results from blood loss, decreased red blood cell (RBC) production, poor RBC maturation, or increased RBC destruction [3, 4]. The WHO defines anemia in adolescents as a haemoglobin value below $11 \mathrm{~g} / \mathrm{dl}$ for children 5-11 years of age, below $12 \mathrm{~g} / \mathrm{dl}$ for children $12-14$ years of age, below $13 \mathrm{~g} / \mathrm{dl}$ in men 15 years of age, and above and below $12 \mathrm{~g} / \mathrm{dl}$ in nonpregnant women 15 years of age and above [2]. Preschool children, pregnant woman, and adolescents constitute a vulnerable group for anemia [5].

According to the World Health Organization (WHO), adolescence has been defined as the period of life between 10 and 19 years of age [6] and constitutes about $25 \%$ of the world population. During adolescence, the velocity of growth is at the faster stage next to the critical window of the 
first 1,000 days of life, and adequate nutrition during this age is very important than any other age. This is the formative period of life when the maximum amount of physical, psychological, and behavioural changes takes place [7].

During childhood and adolescence period, the nutritional needs of boys slightly differ from that of girls. Iron requirements peak during adolescence due to rapid growth and increase in blood volume. Anemia during adolescence causes reduced physical and mental capacity and diminished concentration in work and educational performance, and also poses a major threat to future safe motherhood in girls [8]. Despite the fact that iron is the second most abundant metal in the earth's crust, anemia is considered as the most common micronutrient deficiency worldwide, and in $95 \%$ of cases, it is associated with an iron-poor diet. Iron deficiency is thought to be the most common cause of anemia $[9,10]$.

Globally anemia affects the lives of more than 2 billion people, accounting for over $30 \%$ of the world's population which is the most common public health problem particularly in developing countries occurring at all stages of the life cycle [11]. In developed countries, 4.3 to $20 \%$ of the population, depending on age and gender, are affected by iron deficiency anemia, while in developing countries, these figures range from 30 to $48 \%$ [3]. The worldwide prevalence of anemia among adolescents is $15 \%$ (27\% in developing countries and $6 \%$ in developed countries) [12]. Notwithstanding this, few data are currently available on the prevalence of iron deficiency anemia among adolescents.

Adolescents are at an increased risk of developing anemia due to increased iron demand during puberty, menstrual losses, limited dietary iron intake, and faulty dietary habits. This dramatic increase in iron requirement among adolescents peaks between the ages of 14-15 years for girls and one to two years later for boys. The requirement for iron doubles during adolescence as compared to the younger age group. The overall iron requirement increases two to three folds from a preadolescence level of approximately $0.7-0.9 \mathrm{mg} \mathrm{Fe} /$ day to as much as $1.37-1.88 \mathrm{mg} \mathrm{Fe} /$ day in adolescent boys and 1.40-3.27 mg Fe/day in adolescent girls. This is due to the expansion of total blood volume, increase in lean body mass, and the onset of menstruation in adolescent females $[13,14]$.

In spite of increased iron needs, many adolescents, particularly females have iron intakes of only $10-11 \mathrm{mg} /$ day of total iron, resulting in approximately $1 \mathrm{mg}$ of absorbed. About three fourths of adolescent females and $17 \%$ of males do not get their dietary iron requirement which makes the adolescents vulnerable to the development of anemia [15]. The most common causes of anemia in adolescent, especially in developing countries and Sub-Saharan Africa, are poverty and ignorance that leads to lack of purchasing power to afford foods containing heme iron, low socioeconomic status leader to poor sanitation and hygiene, low iron intake, poor bioavailability of dietary iron, infections, and parasitic infestation [16].

Anemia in adolescent has serious implications for a wide range of outcomes, and nearly all of the functional consequences of iron deficiency are strongly related to the severity of anemia. It causes reduced resistance to infection, impaired physical growth and mental development, and reduced physical fitness, work capacity, and school performance $[17,18]$.

In Ethiopia, adolescents, who constitute a sizable segment of its population, form a vulnerable group and are at a greater risk of morbidity and mortality. Anemia is widely prevalent in Ethiopia and affects both sexes in all age groups. Among adolescents, girls constitute a vulnerable group, particularly in developing countries such as Ethiopia. In a family with limited resources, the female child is more likely to be neglected due to sociocultural factors [19]. In Ethiopia, the prevalence of anemia among the age group of 15-19 year-old males and females was $18.2 \%$ and $19.9 \%$, respectively [20].

Even though the study of anemia among both male and female adolescents is very limited in Ethiopia, few studies have been conducted on school female children, reproductive age women, and pregnant women and the results of all these studies put anemia as a moderate-to-severe public concern. The National Nutrition Program (NNP) of Ethiopia gives special attention to address these age groups, but the implementation of this program at the grass root level is very weak as compared with other vulnerable groups [21].

Therefore, the main aim of this study was to compare the prevalence of anemia and associated factors of anemia among male and female school adolescents in Dilla Town. Results from this research are important to clarify how to approach with adolescent-specific nutrition intervention to reduce anemia-related morbidity and increase productivity. Also, the findings will be used as input for different health sectors at zonal and woreda levels to plan interventions to reduce the problem of anemia.

\section{Methods and Materials}

2.1. Study Design and Setup. A school-based comparative cross-sectional study was conducted from $14^{\text {th }}$ May to $1^{\text {st }}$ June 2018 among school adolescents (10 to 19 years) in Dilla Town, Gedeo Zone, Southern Nations, Nationalities, and Peoples' Region (SNNPR), Southern Ethiopia. Dilla Town is located at $367 \mathrm{~km}$ to the south of Addis Ababa, the capital of the country, and $90 \mathrm{~km}$ from Hawassa, the center of the region, SNNPR. The study area has a longitude and latitude of $6^{\circ} 24^{\prime} 30^{\prime \prime} \mathrm{N} \quad 38^{\circ} 18^{\prime} 30^{\prime \prime} \mathrm{E} \quad$ Coordinates: $6^{\circ} 24^{\prime} 30^{\prime \prime} \mathrm{N}$ $38^{\circ} 18^{\prime} 30^{\prime \prime} \mathrm{E}$, with an elevation of 1570 meters above sea level [22] and monthly temperature range of $10^{\circ} \mathrm{C}$ to $30^{\circ} \mathrm{C}$ [23].

2.2. Population. The source population for this study was all school adolescents from 10 to 19 years attending both private and government schools in Dilla Town, and the study population was adolescents attending the selected schools during the study period. Adolescents with known chronic diseases were excluded from the study.

2.3. Sample Size Determination. The sample size for this study was determined using two population proportion formulas considering prevalence of anemia among male and female taken from a previous cross-sectional study [24]. Accordingly, the sample size was determined using the following formula: 


$$
n=\frac{\left(\left\{Z_{\alpha / 2} \sqrt{2 p q}+Z \beta \sqrt{\left(p_{1} q_{1}\right)}+\sqrt{\left(p_{2} q_{2}\right)}\right\}^{2}\right)}{\Delta^{2}} .
$$

In the formula, $n=$ sample size, $Z_{\alpha / 2}=$ at $95 \% \mathrm{CI}$ which is 1.96 , Power $80 \%$ is $0.84, r=1$ (ratio of exposed to nonexposed), $p_{1}=$ percent of a male with anemia $=24.3 \%=0.243$, $p_{2}=$ percent of a female with anemia $=18.1 \%=0.181$,

$$
\begin{gathered}
p=\frac{p 1+p_{2}}{2}=0.212 \\
q=1-p=0.788 \\
q_{1}=1-p_{1}=0.757 \\
q_{2}=1-p_{2}=0.819 \\
\Delta=p_{1}-p_{2}-0.062
\end{gathered}
$$

The calculated sample based on the above assumption was 688 , and by adding ten percent nonresponse rate, the final sample size became 756 ( 378 males and 378 females).

\subsection{Study Variable}

\subsubsection{Dependent Variable. Adolescent anemia.}

2.4.2. Independent Variables. Demographic characteristics of the adolescents: age of adolescents, place of residence, grade of adolescents, educational status of mother and father, occupational status of mother and father, livening condition (with family or separate from family), parental condition (existence of mother and father), family size, and marital status.

Water and sanitation: source of drinking water, type of latrine, and wear shoe.

Dietary diversity/practice: food consumption, food frequency, food sources, postmeal consumption of tea and coffee, and school feeding program.

Knowledge of anemia: information on anemia, knowledge of food sources rich in iron, knowledge of causes of anemia, and knowledge of consequences of anemia.

Health and nutrition condition: body mass index for age, height for age, menstrual status, malaria endemicity, malaria and parasitic infection, deworming, and accessibility of adolescent health service.

2.5. Sampling Technique/Sampling Procedures. There are a total of 23 schools in Dilla Town out of which six schools were randomly selected with simple random sampling technique. Then, a total sample was proportionally allocated to each schools based on the number of adolescents in the selected schools. Finally, a simple random sampling (SRS) technique was applied to select study participants using the school roaster as a frame.

2.6. Data Collection Procedures and Measurements. For data collection, a pretested questionnaire, anthropometric assessment, haemoglobin measurement, and stool examination checklists were used. The questionnaire was adapted from different literature studies and EDHS [20, 24, 25]. For anthropometric assessment, height and weight were measured with standardized protocols and calibrated equipment. Weights were measured with minimal (light) clothing, shoes removed, and hats using a digital weighting scale (SECA, UNICEF, and Copenhagen) and recorded to the nearest $0.1 \mathrm{~kg}$. Heights were measured using a wooden measuring board with a sliding head bar in Frankfurt position and recorded to the nearest $0.1 \mathrm{~cm} \mathrm{[26].}$

Haemoglobin determination was done for the selected students in the school compound by laboratory technicians that were working outside of the respective district. The haemoglobin concentration of each student was measured by taking a finger-prick blood sample using a HemoCue haemoglobinometer (HemoCue $\mathrm{Hb} 301+$, Angelholm, Sweden). Standardization of the HemoCue haemoglobinometer was checked by crosschecking CBC machine [27]. Both interview and blood sample collection were taken from each adolescent student in a separate room. Haemoglobin measurements were adjusted for altitude, sex, and age as proposed by the WHO, and the cutoff point for anemia was based on the WHO recommendation for adolescents [2].

The stool examination was conducted by laboratory technicians using the portable microscope in each school compound. Stool samples were collected from each study participant using clean, wide-mouthed, and leak-proof stool cups and examined at the data collection site within 10-15 minutes of collection by the wet mount for identification of intestinal parasites.

The food and nutrition technical assistance questionnaire was used to collect data for dietary diversity. The types of food adolescents took within the last 24 hours were asked, and the information collected on dietary consumption was used to calculate the dietary diversity score (DDS).

Data were collected by four laboratory professionals and eight nurse diploma professionals. The data collectors were trained for two days on the data collection tools and anthropometric measurement procedures.

2.7. Data Analysis Procedures. Data were entered into EpiData version 3.1 and then exported to SPSS version 20 statistical packages for analysis. Anthropometric data were entered and calculated using the WHO AnthroPlus software. The dietary diversity scores (DDS) for 24-hour recall were calculated per adolescent by summing the number of different consumed food groups. The DDS was categorized into tertiles which include low dietary diversity with $\leq 2$ food groups, medium dietary diversity with 3 food groups, and high dietary diversity with $\geq 4$ food groups [28]. Stunting was defined using height for age $Z$-score of less than -2 SD. Descriptive statistics were computed to give a clear picture of background 
information and determine the prevalence. Then, data were analyzed using binary and multivariable logistic regression to assess the factors associated with anemia. Model fitness was done using the Hosmer-Lemeshow goodness of fit test for logistic regression. Statistical precision was estimated with 95\% CI (confidence interval) and statistical significance determined at $p$ value $\leq 0.05$.

2.8. Data Quality Management. The questionnaire was originally developed in English and later translated into Amharic and Gedeofa. To keep the consistency of its content, the questionnaire was translated back to English by a language expert. Two-day training was given for data collectors and supervisors. Before data collection, a pretest was conducted among 38 students ( $5 \%$ of the sample size) to centexualize the questionnaires before the actual data collection and revisions were made accordingly. During the study period, the questionnaire was checked every evening for its completeness. Unrecorded data and unlikely responses were manually separated and reinterviewed the next day. All laboratory activities were performed by strictly following manufacturers' instructions and specific standard operating procedures. All anthropometric measurements were taken twice by two data collectors, and the mean values were used for data analysis. The weighing scale was calibrated with a known weight object regularly, and the scale indicator was checked against zero reading after weighing every adolescent.

\section{Results}

3.1. Sociodemographic and Socioeconomic Characteristics. From a total of 756 adolescent students expected to participate in this study, 742 (377 males and 365 females) were actually participated making the response rate $98.1 \%$. Among the participants, about 50\% (186) of males and about $40 \%$ (141) of females were in a late adolescence period with a mean age of 16 years (SD, 2.4) among males and 17 (SD, 2.1) among females. With regard to grade levels, 179 (47.5\%) of males and $190(52.1 \%)$ of females were from grade 5 to 8 . Protestant religion followers constitute 293 (77.7\%) among males and 237 (64.9\%) among females in this study.

Regarding family characteristics, 179 (47.5) of male adolescents and 174 (47.7\%) of female adolescents were from households with a family size of 5-7 members. With respect to family education, 191 (50.7) of males' fathers and 198 (54.2) of females' fathers had attended secondary school or above (Table 1).

3.2. Dietary Practices and Related Factors. Information about the source of food shows that the majority of the family of male $(70.8 \%)$ and female $(76.4 \%)$ adolescents achieve food need through buying/purchasing. Most of the study participants in both sexes $272(72.1 \%)$ among male and 262 (71.8\%) among female had low DDS in the last 24-hour
TABLE 1: Sociodemographic and socioeconomic characteristics of male and female adolescent students in Dilla Town, Gedeo Zone, Southern Ethiopia, May 2018.

\begin{tabular}{|c|c|c|}
\hline Variables & $\begin{array}{c}\text { Male } \\
\text { number (\%) }\end{array}$ & $\begin{array}{c}\text { Female } \\
\text { number (\%) }\end{array}$ \\
\hline Age category & 377 & 365 \\
\hline Early adolescence (10-13 yrs) & $61(16.2)$ & $74(20.3)$ \\
\hline Middle adolescence (14-16 yrs) & $130(34.5)$ & $150(41.1)$ \\
\hline Late adolescence (17-19 yrs) & $186(49.3)$ & $141(38.6)$ \\
\hline Mean age $( \pm \mathrm{SD})$ & $16 \pm 2.4$ & $17 \pm 2.1$ \\
\hline Grade & 377 & 365 \\
\hline $5-8$ & $179(47.5)$ & $190(52.1)$ \\
\hline $9-10$ & $140(37.1)$ & $142(38.9)$ \\
\hline $11-12$ & $58(15.4)$ & $33(9.0)$ \\
\hline Ethnicity & 377 & 365 \\
\hline Gedeo & $258(70.9)$ & $214(61.7)$ \\
\hline Oromo & $44(12.1)$ & $41(11.8)$ \\
\hline Amhara & $31(8.5)$ & $36(10.4)$ \\
\hline Gurage & $25(6.9)$ & $43(12.4)$ \\
\hline Others $^{a}$ & $19(5.0)$ & $31(8.6)$ \\
\hline Religion & 377 & 365 \\
\hline Protestant & $293(77.7)$ & $237(64.9)$ \\
\hline Orthodox & $67(17.8)$ & $95(26.0)$ \\
\hline Muslim & $7(1.9)$ & $21(5.8)$ \\
\hline Catholic & $10(2.7)$ & $12(3.3)$ \\
\hline Father's educational status & 377 & 365 \\
\hline Illiterate/cannot read or write & $26(6.9)$ & $13(3.6)$ \\
\hline Can read and write & $91(24.1)$ & $82(22.5)$ \\
\hline Primary school & $69(18.3)$ & $72(19.7)$ \\
\hline Secondary school and above & $191(50.7)$ & $198(54.2)$ \\
\hline Mother's educational status & 377 & 365 \\
\hline Illiterate/cannot read or write & $65(17.2)$ & $42(11.5)$ \\
\hline Can read and write & $92(24.4)$ & $98(26.8)$ \\
\hline Primary school & $112(29.7)$ & $101(27.7)$ \\
\hline Secondary school and above & $108(28.6)$ & $124(34.0)$ \\
\hline Father's occupational status & 377 & 365 \\
\hline Farmer & $73(19.8)$ & $54(15.3)$ \\
\hline Government employee & $155(42.1)$ & $147(41.8)$ \\
\hline Merchant & $140(38.0)$ & $151(42.9)$ \\
\hline Others $^{b}$ & $9(2.4)$ & $13(3.6)$ \\
\hline Mother's occupational status & 377 & 365 \\
\hline Housewife & $152(41.1)$ & $156(43.9)$ \\
\hline Farmer & $21(5.7)$ & $14(3.9)$ \\
\hline Government employee & $80(21.6)$ & $71(20.0)$ \\
\hline Merchant & $177(31.6)$ & $114(32.1)$ \\
\hline Others $^{c}$ & $7(1.9)$ & $10(2.7)$ \\
\hline Your current marital status & 377 & 365 \\
\hline Never married & $341(90.5)$ & $337(92.3)$ \\
\hline On promise & $25(6.6)$ & $16(4.4)$ \\
\hline Married & $11(2.9)$ & $12(3.3)$ \\
\hline Family size & 377 & 365 \\
\hline$\leq 4$ & $35(9.3)$ & $33(9.0)$ \\
\hline $5-7$ & $179(47.5)$ & $174(47.7)$ \\
\hline$\geq 8$ & $163(43.2)$ & $158(43.3)$ \\
\hline Place of residence & 377 & 365 \\
\hline Urban & $329(87.3)$ & $337(92.3)$ \\
\hline Rural & $48(12.7)$ & $28(7.7)$ \\
\hline
\end{tabular}


TABLE 1: Continued.

\begin{tabular}{lcc}
\hline Variables & $\begin{array}{c}\text { Male } \\
\text { number (\%) }\end{array}$ & $\begin{array}{c}\text { Female } \\
\text { number }(\%)\end{array}$ \\
\hline Parental status & 377 & 365 \\
Both parent alive & $343(91.0)$ & $333(91.2)$ \\
Father alive & $7(1.9)$ & $6(1.6)$ \\
Mother alive & $23(6.1)$ & $25(6.8)$ \\
Both parent died & $4(1.1)$ & $1(0.3)$ \\
\hline Current living status & 377 & 365 \\
Living with parent & $305(80.9)$ & $316(86.6)$ \\
Living with relatives & $18(4.8)$ & $26(7.1)$ \\
Living separately from family & $54(14.3)$ & $23(6.3)$ \\
\hline
\end{tabular}

$\bar{a}=$ Wolaita, Silte, Sidama, and others; ${ }^{b}=$ private employee, daily laborer, student, and others; ${ }^{c}=$ private employee, daily laborer, and student.

recall. Concerning daily meal frequency, 335 (88.9\%) of male adolescents and $342(93.7 \%)$ female adolescents eat three times or more (Table 2).

3.3. Health Services, Personal Practices, and Related Factors. About 50\% (140) of males and $43.2 \%$ (115) of female respondents have poor knowledge about anemia. About 10.3\% (39) of male adolescents and 9.6\% (35) of female adolescents have history of malaria infection in the last one month. Regarding stool parasite assessment result, 104 (31.5\%) of male study participants and 78 (22.0\%) of female adolescents have parasite infestation (Table 3).

3.4. Prevalence of Anemia and Anthropometric Measurements. In this study, the overall prevalence of anemia was $157(21.1 \%)$ and it is $85(22.5 \%)$ among male adolescents and $72(19.7 \%)$ among female adolescents. The mean haemoglobin levels were $14.4( \pm 2.3)$ among male and $13.4( \pm 1.9)$ among female study participants. Regarding nutritional status of the adolescents, the level of stunting was 48 (12.7\%) among males and 37 (10.1\%) among females. According to BMI Zscore for age result, 39 (10.3\%) of male adolescents and 19 (5.2\%) of female adolescents were thin (Table 4).

3.5. Factors Associated with Anemia among School Adolescents in Dilla Town. The multivariable analysis result showed that age category, the frequency of eating fibre foods, and presence of stool parasites were significantly associated with the prevalence of anemia among male adolescent students and malaria endemicity and presence of stool parasites were significantly associated with the prevalence of anemia among female adolescent students.

With regard to factors associated with anemia among males, adolescents in the age range of $10-13$ years were $76 \%$ less likely to develop anemia (AOR 0.24, 95\% CI, 0.07-0.77) compared to those respondents in the age group of 17-19 years. Adolescent males who eat fibre foods every day were $88 \%$ less likely to develop anemia compared to those who eat none through the week days (AOR 0.12, 0.02-0.64). Adolescent males who have no stool parasite were $99.5 \%$ less likely to develop anemia than adolescent males who have stool parasite (AOR 0.05, 95\% CI, 0.02-0.09).
TABLE 2: Dietary practices and related factors among male and female adolescent students in Dilla Town, Gedeo Zone, Southern Ethiopia, May 2018.

\begin{tabular}{|c|c|c|}
\hline Variables & $\begin{array}{c}\text { Male } \\
(n=377) \\
\text { number } \\
(\%)\end{array}$ & $\begin{array}{c}\text { Female } \\
(n=365) \text { number } \\
(\%)\end{array}$ \\
\hline Daily meal frequency (usual) & 377 & 365 \\
\hline Two times or below & $42(11.1)$ & $23(6.3)$ \\
\hline Three times or more & $335(88.9)$ & $342(93.7)$ \\
\hline $\begin{array}{l}\text { Daily meal frequency ( } 24 \\
\text { hours) }\end{array}$ & 377 & 365 \\
\hline Two times or below & $113(30.0)$ & $83(22.7)$ \\
\hline Three times or more & $264(70.0)$ & $282(77.3)$ \\
\hline $\begin{array}{l}\text { Main sources of family food } \\
\text { needs }\end{array}$ & 377 & 365 \\
\hline Grow their own & $99(26.3)$ & $74(20.3)$ \\
\hline Buy/purchase & $267(70.8)$ & $279(76.4)$ \\
\hline Subsidies/food aid & $11(2.9)$ & $12(3.3)$ \\
\hline DDS in last 24 hours & 377 & 365 \\
\hline Low & $272(72.1)$ & $262(71.8)$ \\
\hline Medium & $100(26.5)$ & $99(27.1)$ \\
\hline High & $5(1.3)$ & $4(1.1)$ \\
\hline $\begin{array}{l}\text { Green leafy vegetable } \\
\text { consumption }\end{array}$ & 377 & 365 \\
\hline None & $15(4.0)$ & $20(5.5)$ \\
\hline Once a week & $53(14.1)$ & $32(8.8)$ \\
\hline Twice in a week & $98(26.0)$ & $99(27.1)$ \\
\hline Every other day & $80(21.2)$ & $74(20.3)$ \\
\hline Every day & $87(23.1)$ & $86(23.6)$ \\
\hline Do not remember & $44(11.7)$ & $54(14.8)$ \\
\hline Frequency of fibre foods & 377 & 365 \\
\hline None & $24(6.4)$ & $29(7.9)$ \\
\hline Once a week & $83(22.0)$ & $61(16.7)$ \\
\hline Twice in a week & $71(18.8)$ & $81(22.2)$ \\
\hline Every other day & $61(16.2)$ & 47 (12.9) \\
\hline Every day & $67(17.8)$ & $81(22.2)$ \\
\hline Do not remember & $71(18.8)$ & $66(18.1)$ \\
\hline $\begin{array}{l}\text { Frequency of foods of animal } \\
\text { origin }\end{array}$ & 377 & 365 \\
\hline None & $34(9.0)$ & $21(5.8)$ \\
\hline Once a week & $147(39.0)$ & $118(32.3)$ \\
\hline Twice in a week & $75(19.9)$ & $105(28.8)$ \\
\hline Every other day & $38(10.1)$ & $48(13.2)$ \\
\hline Every day & $42(11.1)$ & $41(11.2)$ \\
\hline Do not remember & $41(10.9)$ & $32(8.8)$ \\
\hline $\begin{array}{l}\text { Consumption of tea after a } \\
\text { meal }\end{array}$ & 377 & 365 \\
\hline Always & $118(31.3)$ & $123(33.7)$ \\
\hline Sometimes & $207(54.9)$ & $194(53.2)$ \\
\hline Not at all & $40(10.6)$ & $33(9.0)$ \\
\hline Do not remember & $12(3.2)$ & $15(4.1)$ \\
\hline
\end{tabular}

Adolescent females from malaria endemic area were 2.5 times more likely to develop anemia than adolescent females from the less endemic area (AOR 2.52, 95\% CI, 1.12-5.62). Adolescent females who have no intestinal parasite were 99.5\% less likely to develop anemia than adolescent females who have intestinal parasite (AOR 0.05, 95\% CI, 0.01-0.11) (Table 5). 
TABLE 3: Health service, personal practices, and related factors among male and female adolescent students in Dilla Town, Gedeo Zone, Southern Ethiopia, May 2018.

\begin{tabular}{|c|c|c|}
\hline Variables & Male $(n=377)$ number $(\%)$ & Female $(n=365)$ number $(\%)$ \\
\hline $\begin{array}{l}\text { Knowledge of anemia } \\
\text { Good knowledge } \\
\text { Poor knowledge }\end{array}$ & $\begin{array}{c}281 \\
141(50.2) \\
140(49.8)\end{array}$ & $\begin{array}{c}266 \\
151(56.8) \\
115(43.2)\end{array}$ \\
\hline $\begin{array}{l}\text { Malaria endemicity } \\
\text { Yes } \\
\text { No }\end{array}$ & $\begin{array}{c}377 \\
184(48.8) \\
193(51.2)\end{array}$ & $\begin{array}{c}365 \\
178(48.8) \\
187(51.2)\end{array}$ \\
\hline $\begin{array}{l}\text { History of malaria last one month } \\
\text { Yes } \\
\text { No }\end{array}$ & $\begin{array}{c}377 \\
39(10.3) \\
338(89.7) \\
\end{array}$ & $\begin{array}{c}365 \\
35(9.6) \\
330(90.4)\end{array}$ \\
\hline $\begin{array}{l}\text { Deworming in the last one month } \\
\text { Yes } \\
\text { No }\end{array}$ & $\begin{array}{c}377 \\
48(12.7) \\
329(87.3) \\
\end{array}$ & $\begin{array}{c}365 \\
62(17.0) \\
303(83.0)\end{array}$ \\
\hline $\begin{array}{l}\text { Menstruation } \\
\text { Yes } \\
\text { No }\end{array}$ & & $\begin{aligned} & 365 \\
329 & (90.1) \\
36 & (9.9)\end{aligned}$ \\
\hline $\begin{array}{l}\text { Days of menstruation } \\
<3 \text { days } \\
>3 \text { days }\end{array}$ & & $\begin{array}{c}329 \\
183(55.6) \\
146(44.4) \\
\end{array}$ \\
\hline $\begin{array}{l}\text { Frequency of pad change } \\
<3 \text { times } \\
>3 \text { times }\end{array}$ & & $\begin{array}{c}329 \\
271(82.4) \\
58(17.6) \\
\end{array}$ \\
\hline $\begin{array}{l}\text { Source of drinking water } \\
\text { Piped water } \\
\text { Stand pipe } \\
\text { Protected spring }\end{array}$ & $\begin{array}{c}377 \\
295(78.2) \\
31(8.2) \\
51(13.5)\end{array}$ & $\begin{aligned} & 365 \\
318 & (87.1) \\
20 & (5.5) \\
27 & (7.4)\end{aligned}$ \\
\hline $\begin{array}{l}\text { Shoe wearing frequency } \\
\text { Some of the time } \\
\text { Most of the time } \\
\text { Always }\end{array}$ & $\begin{array}{c}377 \\
90(23.9) \\
87(23.1) \\
200(53.1)\end{array}$ & $\begin{array}{c}365 \\
35(9.6) \\
44(12.1) \\
286(78.4)\end{array}$ \\
\hline
\end{tabular}

TABle 4: Prevalence of anemia among male and female adolescents in Dilla Town, Southern Ethiopia, May 2018.

\begin{tabular}{lcc}
\hline Variables & $\begin{array}{c}\text { Male }(n=377) \\
\text { Number }(\%)\end{array}$ & $\begin{array}{c}\text { Female }(n=365) \\
\text { Number }(\%)\end{array}$ \\
\hline Anemia status & 377 & 365 \\
Anemic & $85(22.5)$ & $72(19.7)$ \\
Nonanemic & $292(77.5)$ & $293(80.3)$ \\
\hline Types of anemia & 85 & 72 \\
Sever & $1(0.3)$ & $4(1.1)$ \\
Moderate & $46(12.2)$ & $43(11.8)$ \\
Mild & $38(10.1)$ & $25(6.8)$ \\
Mean (SD) & $14.4 \pm 2.3$ & $13.4 \pm 1.9$ \\
\hline HAZ & 377 & 365 \\
Stunted & $48(12.7)$ & $37(10.1)$ \\
Normal & $329(87.3)$ & $328(89.9)$ \\
\hline BAZ & 377 & 365 \\
Thin & $39(10.3)$ & $19(5.2)$ \\
Normal & $338(89.7)$ & $346(94.8)$ \\
\hline
\end{tabular}

\section{Discussion}

The result of this study indicated that the overall prevalence of anemia among adolescents in the study areas was $21.1 \%$. According to the WHO established criterion, this prevalence is of a moderate public health concern. The comparative assessment revealed that male adolescents (22.5\%) were slightly more anemic than female (19.3\%) adolescents. However, the difference was found to be not statistically significant. Another finding of a study conducted among adolescents in Wonago District, Gedeo Zone, Southern Ethiopia, found significantly higher prevalence of anemia among male adolescents $(24.3 \%)$ than among female adolescents (18.1\%) [24]. The finding from South Kerala in India also found that male adolescents were more anemic than female adolescents [29]. However, the finding of the study conducted in Bonga Town, Southwest Ethiopia, found that the prevalence of anemia among male adolescents was lower among males (9.4\%) than females (19.3\%) [25]. This might be due to certain difference in the population included in the study conducted in Bonga Town where the study included older adolescents, and the higher prevalence of anemia among females might be due to mensus. The finding of this study in this regard implies that the trend of considering male adolescents as a less vulnerable group to anemia than the female counterparts in programs attempting to intervene nutritional problems such as anemia should be reconsidered.

Regarding the overall prevalence, the result of this study revealed that the prevalence of anemia was comparable to the other studies in Ethiopia including those conducted in 
TABle 5: Associated factors of anemia among male and female adolescent students in Dilla Town, Southern Ethiopia, May 2018.

\begin{tabular}{|c|c|c|c|c|c|c|c|c|}
\hline \multirow{2}{*}{ Variables } & \multicolumn{4}{|c|}{ Male } & \multicolumn{4}{|c|}{ Female } \\
\hline & Anemic & Nonanemic & COR $(95 \% \mathrm{CI})$ & AOR $(95 \% \mathrm{CI})$ & Anemic & Nonanemic & COR $(95 \% \mathrm{CI})$ & $\operatorname{AOR}(95 \% \mathrm{CI})$ \\
\hline Age & 85 & 292 & & & 72 & 293 & & \\
\hline $10-13$ & $\begin{array}{c}25 \\
(41.0)\end{array}$ & $36(59.0)$ & $\begin{array}{c}0.29 \\
(0.15-0.55)^{*}\end{array}$ & $\begin{array}{c}0.24 \\
(0.07-0.77)^{*}\end{array}$ & $\begin{array}{c}29 \\
(39.2)\end{array}$ & 45 (61.8) & $0.27(0.14-0.52)^{*}$ & $0.27(0.05-1.38)$ \\
\hline $13-16$ & $\begin{array}{c}29 \\
(22.3)\end{array}$ & $101(77.7)$ & $\begin{array}{c}0.69 \\
(0.39-1.23)\end{array}$ & $0.44(0.17-1.11)$ & $22(14.7)$ & $128(85.3)$ & $1.02(0.53-1.95)$ & $0.90(0.30-2.66)$ \\
\hline $17-19$ & $31(16.7)$ & $155(83.3)$ & 1 & 1 & $21(14.9)$ & $120(85.1)$ & 1 & 1 \\
\hline Grade & 85 & 292 & & & 72 & 293 & & \\
\hline $5-8$ & $\begin{array}{c}51 \\
(28.5)\end{array}$ & $128(71.5)$ & 1 & 1 & $\begin{array}{c}46 \\
(24.2)\end{array}$ & $144(75.8)$ & 1 & 1 \\
\hline $9-10$ & $24(17.1)$ & $116(82.9)$ & $\begin{array}{c}1.93 \\
(1.12-3.33)^{*}\end{array}$ & $0.62(0.24-1.58)$ & $21(14.8)$ & $121(85.2)$ & $1.84(1.04-3.25)^{*}$ & $1.63(0.57-4.63)$ \\
\hline $11-12$ & $\begin{array}{c}10 \\
(17.2) \\
\end{array}$ & $48(82.8)$ & $\begin{array}{c}1.91 \\
(0.89-4.07) \\
\end{array}$ & $0.56(0.14-2.10)$ & $5(15.2)$ & $28(84.8)$ & $1.79(0.65-4.90)$ & $0.84(0.14-4.79)$ \\
\hline Father's education & 85 & 292 & & & 72 & 293 & & \\
\hline $\begin{array}{l}\text { No formal } \\
\text { education }\end{array}$ & $8(30.8)$ & $18(69.2)$ & $\begin{array}{c}0.73 \\
(0.30-1.79)\end{array}$ & & $3(23.1)$ & $10(76.9)$ & $0.64(0.17-2.46)$ & $0.39(0.06-2.47)$ \\
\hline Read and write & $\begin{array}{c}14 \\
(15.4)\end{array}$ & $77(84.6)$ & $\begin{array}{c}1.79 \\
(0.93-3.47)\end{array}$ & & $\begin{array}{c}22 \\
(26.8)\end{array}$ & $60(73.2)$ & $0.53(0.28-0.97)^{*}$ & $0.57(0.18-1.73)$ \\
\hline Primary school & $\begin{array}{c}16 \\
(23.2)\end{array}$ & $53(76.8)$ & $\begin{array}{c}1.08 \\
(0.56-2.07)\end{array}$ & & $\begin{array}{c}15 \\
(20.8)\end{array}$ & $57(79.2)$ & $0.73(0.37-1.45)$ & $0.89(0.27-2.91)$ \\
\hline $\begin{array}{l}\text { Secondary and } \\
\text { above }\end{array}$ & $\begin{array}{c}47 \\
(24.6) \\
\end{array}$ & $144(75.4)$ & 1 & & $32(16.2)$ & $166(83.8)$ & 1 & 1 \\
\hline $\begin{array}{l}\text { Father's } \\
\text { occupation }\end{array}$ & 85 & 292 & & & 72 & 293 & & \\
\hline Farmer & $\begin{array}{c}13 \\
(17.8)\end{array}$ & $60(82.2)$ & 1 & & $7(13.0)$ & $47(87.0)$ & 1 & 1 \\
\hline $\begin{array}{l}\text { Government } \\
\text { employee }\end{array}$ & $\begin{array}{c}35 \\
(22.6)\end{array}$ & $120(76.4)$ & $\begin{array}{c}0.74 \\
(0.36-1.50)\end{array}$ & & $21(14.3)$ & $126(85.7)$ & $0.89(0.35-2.23)$ & $2.00(0.42-9.53)$ \\
\hline Merchant & $\begin{array}{c}36 \\
(25.7)\end{array}$ & $104(74.3)$ & $\begin{array}{c}0.63 \\
(0.31-1.27)\end{array}$ & & $\begin{array}{c}43 \\
(28.5)\end{array}$ & $108(71.5)$ & $0.37(0.15-0.89)^{*}$ & $1.38(0.36-5.20)$ \\
\hline Others & $1(11.1)$ & $8(88.9)$ & $\begin{array}{c}0.80 \\
(0.57-1.12)\end{array}$ & & $1(7.7)$ & $12(92.3)$ & $0.53(0.35-0.80)^{*}$ & $0.26(0.01-4.16)$ \\
\hline $\begin{array}{l}\text { Mother's } \\
\text { occupation }\end{array}$ & 85 & 292 & & & 72 & 292 & & \\
\hline Housewife & $\begin{array}{c}37 \\
(24.3)\end{array}$ & $115(75.7)$ & 1 & & $26(16.7)$ & $130(83.3)$ & 1 & 1 \\
\hline Farmer & $4(19.1)$ & $17(80.9)$ & $\begin{array}{c}1.37 \\
(0.43-4.32)\end{array}$ & & $1(7.1)$ & $13(92.9)$ & $2.60(0.32-20.75)$ & $\begin{array}{c}1.31 \\
(0.11-15.72)\end{array}$ \\
\hline $\begin{array}{l}\text { Government } \\
\text { employee }\end{array}$ & $\begin{array}{c}17 \\
(21.3)\end{array}$ & $63(78.7)$ & $\begin{array}{c}1.19 \\
(0.62-2.29)\end{array}$ & & $11(15.5)$ & $60(84.5)$ & $1.09(0.51-2.35)$ & $0.79(0.25-2.47)$ \\
\hline Merchant & $\begin{array}{c}24 \\
(20.5)\end{array}$ & $93(79.5)$ & $\begin{array}{c}1.25 \\
(0.69-2.23)\end{array}$ & & $\begin{array}{c}33 \\
(29.8)\end{array}$ & $80(70.2)$ & $0.47(0.26-0.84)^{*}$ & $0.68(0.27-1.69)$ \\
\hline Others & $3(42.9)$ & $4(57.1)$ & $\begin{array}{c}1.08 \\
(0.89-1.29) \\
\end{array}$ & & $1(10.0)$ & $9(90.0)$ & $0.73(0.59-0.87)^{*}$ & $\begin{array}{c}1.29 \\
(0.14-11.19) \\
\end{array}$ \\
\hline Shoe wearing & 85 & 292 & & & 72 & 293 & & \\
\hline Some of the time & $\begin{array}{c}17 \\
(18.9)\end{array}$ & $73(81.1)$ & $\begin{array}{c}1.47 \\
(0.79-2.72)\end{array}$ & & $6(17.1)$ & $29(82.9)$ & $0.95(0.37-2.42)$ & $1.19(0.30-4.79)$ \\
\hline Most of the time & $\begin{array}{c}17 \\
(19.5)\end{array}$ & $70(80.5)$ & $\begin{array}{c}1.41 \\
(0.76-2.61)\end{array}$ & & $\begin{array}{c}19 \\
(43.2)\end{array}$ & $25(56.8)$ & $0.26(0.13-0.50)^{*}$ & $0.39(0.12-1.27)$ \\
\hline Always & $\begin{array}{c}51 \\
(25.5) \\
\end{array}$ & $149(84.5)$ & 1 & & $47(16.4)$ & $239(83.6)$ & 1 & 1 \\
\hline $\begin{array}{l}\text { Sources of family } \\
\text { food }\end{array}$ & 85 & 292 & & & 72 & 293 & & \\
\hline Grow their own & $\begin{array}{c}18 \\
(18.2)\end{array}$ & $81(81.8)$ & 1 & & $8(10.8)$ & $66(89.2)$ & 1 & 1 \\
\hline Buy/purchase & $\begin{array}{c}65 \\
(24.3)\end{array}$ & $202(75.7)$ & $\begin{array}{c}0.69 \\
(0.38-1.23)\end{array}$ & & $\begin{array}{c}62 \\
(22.2)\end{array}$ & $217(77.8)$ & $0.42(0.19-0.93)^{*}$ & $0.55(0.17-1.67)$ \\
\hline Subsidies/food aid & $2(18.2)$ & $9(81.8)$ & $\begin{array}{c}1.00 \\
(0.19-5.02) \\
\end{array}$ & & $2(16.7)$ & $10(83.3)$ & $0.61(0.11-3.27)$ & $\begin{array}{c}5.85 \\
(0.33-101.37) \\
\end{array}$ \\
\hline
\end{tabular}


TABle 5: Continued.

\begin{tabular}{|c|c|c|c|c|c|c|c|c|}
\hline \multirow{2}{*}{ Variables } & \multicolumn{4}{|c|}{ Male } & \multicolumn{4}{|c|}{ Female } \\
\hline & Anemic & Nonanemic & COR $(95 \% \mathrm{CI})$ & AOR $(95 \% \mathrm{CI})$ & Anemic & Nonanemic & COR $(95 \% \mathrm{CI})$ & AOR $(95 \% \mathrm{CI})$ \\
\hline $\begin{array}{l}\text { Fibre foods per } \\
\text { week }\end{array}$ & 85 & 292 & & & 72 & 293 & & \\
\hline None & $4(16.7)$ & $20(83.3)$ & 1 & 1 & $4(13.8)$ & $25(86.2)$ & 1 & 1 \\
\hline Once a week & $\begin{array}{c}11 \\
(13.3)\end{array}$ & $72(86.7)$ & $\begin{array}{c}1.31 \\
(0.37-4.55)\end{array}$ & $0.68(0.12-3.67)$ & $11(18.0)$ & $50(82.0)$ & $0.73(0.21-2.52)$ & $0.53(0.09-2.94)$ \\
\hline Twice in a week & $\begin{array}{c}18 \\
(25.4)\end{array}$ & $53(74.6)$ & $\begin{array}{c}0.59 \\
(0.17-1.95)\end{array}$ & $0.24(0.04-1.27)$ & $8(9.9)$ & $73(90.1)$ & $\begin{array}{c}1.460 \\
(0.40-5.26)\end{array}$ & $\begin{array}{c}3.36 \\
(0.50-22.24)\end{array}$ \\
\hline Every other day & $\begin{array}{c}11 \\
(18.0)\end{array}$ & $50(82.0)$ & $\begin{array}{c}0.91 \\
(0.26-3.19)\end{array}$ & $0.61(0.11-3.36)$ & $\begin{array}{c}12 \\
(25.5)\end{array}$ & $35(74.5)$ & $0.47(0.13-1.61)$ & $0.73(0.13-4.12)$ \\
\hline Every day & $\begin{array}{c}27 \\
(40.3)\end{array}$ & $40(59.7)$ & $\begin{array}{c}0.29 \\
(0.09-0.96)^{*}\end{array}$ & $\begin{array}{c}0.12 \\
(0.02-0.64)^{*}\end{array}$ & $\begin{array}{c}28 \\
(34.6)\end{array}$ & $53(65.4)$ & $0.30(0.09-0.95)^{*}$ & $0.63(0.12-3.11)$ \\
\hline Do not remember & $\begin{array}{c}14 \\
(19.7) \\
\end{array}$ & $57(80.3)$ & $\begin{array}{c}0.81 \\
(0.24-2.76) \\
\end{array}$ & $0.55(0.10-2.95)$ & $9(13.6)$ & $57(86.4)$ & $1.01(0.28-3.60)$ & $1.55(0.26-9.06)$ \\
\hline $\begin{array}{l}\text { Animal food per } \\
\text { week }\end{array}$ & 85 & 292 & & & 72 & 293 & & \\
\hline None & $3(9.1)$ & $31(90.9)$ & 1 & 1 & $6(28.6)$ & $15(71.4)$ & 1 & \\
\hline Once a week & $\begin{array}{c}38 \\
(25.9)\end{array}$ & $109(84.1)$ & $\begin{array}{c}0.28 \\
(0.08-0.96)^{*}\end{array}$ & $0.36(0.08-1.58)$ & $20(16.9)$ & $98(73.1)$ & $1.96(0.67-5.66)$ & \\
\hline Twice in a week & $\begin{array}{c}16 \\
(21.3)\end{array}$ & $59(78.7)$ & $\begin{array}{c}0.36 \\
(0.09-1.32)\end{array}$ & $0.43(0.09-2.09)$ & $20(19.0)$ & $85(81.0)$ & $1.70(0.58-4.93)$ & \\
\hline Every other day & $8(21.1)$ & $30(78.9)$ & $\begin{array}{c}0.36 \\
(0.08-1.49)\end{array}$ & $0.64(0.11-3.61)$ & $9(18.8)$ & $39(81.2)$ & $1.73(0.52-5.71)$ & \\
\hline Every day & $\begin{array}{c}11 \\
(26.2)\end{array}$ & $31(73.8)$ & $\begin{array}{c}0.27 \\
(0.06-1.07)\end{array}$ & $0.74(0.13-4.01)$ & $\begin{array}{c}11 \\
(26.8)\end{array}$ & $30(73.2)$ & $1.09(0.33-3.52)$ & \\
\hline Do not remember & $9(22.0)$ & $32(78.0)$ & $\begin{array}{c}0.34 \\
(0.08-1.39)\end{array}$ & $0.40(0.07-2.23)$ & $6(18.8)$ & $26(81.2)$ & $1.73(0.47-6.34)$ & \\
\hline Stool parasite & 82 & 272 & & & 63 & 267 & & \\
\hline No & $\begin{array}{c}30 \\
(10.9)\end{array}$ & $246(89.1)$ & $\begin{array}{c}0.06 \\
(0.03-0.11)^{*}\end{array}$ & $\begin{array}{c}0.05 \\
(0.02-0.09)^{*}\end{array}$ & $13(5.8)$ & $213(94.2)$ & $0.07(0.03-0.13)^{*}$ & $\begin{array}{c}0.05 \\
(0.01-0.11)^{*}\end{array}$ \\
\hline Yes & $\begin{array}{c}52 \\
(66.7) \\
\end{array}$ & $26(33.3)$ & 1 & 1 & $50(48.1)$ & $54(51.9)$ & 1 & 1 \\
\hline $\begin{array}{l}\text { Malaria } \\
\text { endemicity }\end{array}$ & 85 & 292 & & & 67 & 293 & & \\
\hline Yes & $\begin{array}{c}37 \\
(20.1)\end{array}$ & $147(79.9)$ & $\begin{array}{c}1.31 \\
(0.80-2.13)\end{array}$ & & $27(15.2)$ & $151(84.8)$ & $1.77(1.04-3.00)^{*}$ & $\begin{array}{c}2.52 \\
(1.12-5.62)^{*}\end{array}$ \\
\hline No & $\begin{array}{c}48 \\
(24.9) \\
\end{array}$ & $145(75.1)$ & 1 & & $45(24.1)$ & $142(75.9)$ & 1 & 1 \\
\hline $\begin{array}{l}\text { Start } \\
\text { menstruating }\end{array}$ & & & & & 72 & 293 & & \\
\hline Yes & & & & & $57(17.3)$ & $272(82.7)$ & 1 & 1 \\
\hline No & & & & & $15(41.7)$ & $21(58.3)$ & $0.29(0.14-0.60)^{*}$ & $\begin{array}{c}2.56 \\
(0.53-12.28)\end{array}$ \\
\hline
\end{tabular}

*Statistically significant at $p<0.05 ; \mathrm{COR}=$ crudes odds ratio; $\mathrm{AOR}=$ adjusted odds ratio.

Wonago Town [24] and Bonga Town [25]. On the other hand, the overall prevalence is much lower than the study conducted in India $(62.0 \%$ in females and $46.1 \%$ in males, respectively) [29] and Chennai, Tamil Nadu, among adolescent female students which found $78.8 \%$ [30]. The difference in the finding of our study from different regions of the world could be due to the difference in cultural and behavioural practices in different areas of the world. This could also be due to Ethiopia being the country with widespread teff, cereal rich in iron, consuming country than other developing countries.
In the present study, the prevalence of anemia among adolescent males whose age 10-13 years is lower than the prevalence among adolescent males with an age group of 17-19 years. This study is not in agreement with another comparable study conducted in Wonago District, Gedeo Zone, which indicated anemia to be higher among early adolescent periods (10-13 years) compared to the late adolescent period (17-19 years) [24]. The differences may be due to the larger number of menstruating adolescents (females) in this study compared to the previous one. 
This study also revealed that adolescent males who eat fibre foods every day were less likely to develop anemia than adolescent males who eat none throughout the weeks. This finding is in line with the study done in Alexandria, Egypt, which reported high consumption of whole wheat bread and bread, low dietary intake of iron-rich foods, and low consumption of vitamin $\mathrm{C}$ rich foods to have a significant association with anemia [31]. This suggests that dietary iron intake in fruits and other vegetables is good sources of Vit-A and Vit-C and those food items are also good iron absorption enhancers [32]. Adolescent males who have no intestinal parasite were less likely to develop anemia than adolescent males who have intestinal parasites. This finding is also in agreement with the finding reported from Bonga Town, Southwest Ethiopia, which indicated intestinal parasite infection as one of the factors increasing the risk of anemia among adolescents [25]. This might be due to the fact that most identified intestinal parasites have their own contribution to blood loss and/or red cell destruction [33].

Regarding the factors associated with anemia among adolescent females, those coming from where malaria was common in their area were more likely to develop anemia than adolescent females for whom malaria is not common in their area of residence. This is because malaria is a main cause of anemia in adolescents in Sub-Saharan Africa, and it behaves such as an endemic disease in some areas, such as Ethiopia. Malaria infection is associated with a reduction in haemoglobin levels by the destruction of red blood cells, frequently leading to anemia. This study also identified that the prevalence of anemia among female adolescents who had been infected with intestinal parasites was significantly higher compared to those not infected with intestinal parasites. A similar finding was reported from a study conducted in Siaya District, Kenya; female adolescents who were infected by worms were to develop anemia as opposed to those who did not have worm infestation [34]. This finding is also in contrary to a similar study conducted in Tigray, Northern Ethiopia [35]. This implies that intestinal parasites have also their own contribution for developing anemia among females.

The current study attemted to reveal the level of anemia among male and female adolescents employing a comparative cross-sectional study to have enough sample among the comparison groups. It also addressed a wide range of factors that are associated with anemia in both sexes. The measurement used to assess anemia using HemoCue $\mathrm{Hb} 301+$ machine is precise and accurate proxy indicator for anemia study. The limitation of this study was the exclusion of adolescents who are out of school. In addition, there could also be a socialdesirability bias in dietary questions asked for food habit.

\section{Conclusion}

The prevalence of anemia was higher in male adolescent students than females. Age, the frequency of eating fibre foods, and intestinal parasites were significantly associated factors for anemia among male adolescents, and malaria endemicity and stool parasites were factors significantly associated with anemia among female adolescent students. Hence, nutrition programs focusing on anemia among adolescents should give due consideration for both sexes and male adolescents need to have more emphasis. Furthermore, stronger studies with better designs need to be conducted to confirm this finding and to come up with concrete evidence for policy making.

\section{Data Availability}

The data underlying this study are readily available and can be accessed as needed from the corresponding author.

\section{Ethical Approval}

The ethical clearance letter to conduct this study was obtained from the Institutional Review Board (IRB) of Dilla University, College of Health Sciences and Medicine. Permission to conduct the study was obtained from each school director's office. The data collectors explained the objectives and benefits of the study for study participants to obtain informed written consent prior to data collection. The authors obtained written informed consent from 18- to 19year-old study participants and assent from guardians of less than 18-year-old study participants. Participants confirmed as severe anemic and having an intestinal parasitic infection were linked to the nearby health facility.

\section{Disclosure}

There was no role of the funding body in designing, execution of the study, and writeup of the manuscript.

\section{Conflicts of Interest}

There are no conflicts of interest among the authors.

\section{Authors' Contributions}

$\mathrm{MB}, \mathrm{MF}$, and $\mathrm{SH}$ conceived the idea, designed the methodology, analyzed data, interpreted the finding, and drafted the manuscript. AT participated in data analysis, interpretation, and manuscript writeup. All authors have read and approved the manuscript.

\section{Acknowledgments}

The authors are grateful to the Dilla University NORHED/ SENUPH project for financial coverage and Gedeo Zone Education Office for their cooperation. Also, our heartfelt gratitude goes to supervisors, data collectors, and study participants. The funding for undertaking this study was obtained from the Dilla University NORHED/SENUPH project.

\section{References}

[1] E. Beutler and J. Waalen, "The definition of anemia: what is the lower limit of normal of the blood hemoglobin concentration?," Blood, vol. 107, no. 5, pp. 1747-1750, 2006.

[2] World Health Organization, Haemoglobin Concentrations for the Diagnosis of Anaemia and Assessment of Severity, Vitamin 
and Mineral Nutrition Information System, WHO, Geneva, Switzerland, 2011.

[3] World Health Organization, The Global Prevalence of Anaemia in 2011, WHO, Geneva, Switzerland, 2015.

[4] E. J. Benz, N. Berliner, and F. J. Schiffman, Anaemia: Pathophysiology, Diagnosis and Management, Cambridge University Press, Cambridge, UK, 2018.

[5] World Health Organization, Worldwide Prevalence of Anaemia 1993-2005: WHO Global Database on Anaemia, WHO, Geneva, Switzerland, 2008.

[6] World Health Organization, Young People's Health: A Challenge for Society: Report of a WHO Study Group on Young People and "Health for All by the Year 2000", WHO, Geneva, Switzerland, 1986.

[7] S. Rati and S. Jawadagi, "Prevalence of anemia among adolescent girls studying in selected schools," IJSR, vol. 3, no. 8, pp. 1237-1242, 2014.

[8] G. B. Forbes, Human Body Composition: Growth, Aging, Nutrition, and Activity, Springer Science \& Business Media, Berlin, Germany, 2012.

[9] C. Camaschella, "Iron-deficiency anemia," New England Journal of Medicine, vol. 372, no. 19, pp. 1832-1843, 2015.

[10] E. McLean, M. Cogswell, I. Egli, D. Wojdyla, and B. De Benoist, "Worldwide prevalence of anaemia, WHO vitamin and mineral nutrition information system, 1993-2005," Public Health Nutrition, vol. 12, no. 4, pp. 444-454, 2009.

[11] A. Prayag, G. S. Ashtagi, and M. D. Mallapur, "A study on assessment of severity of anaemia among urban and rural children of Belagavi, Karnataka," National Journal of Community Medicine, vol. 7, no. 8, pp. 708-711, 2016.

[12] Y. I. Balcı, A. Karabulut, D. Gürses, and I. Ethem Çövüt, "Prevalence and risk factors of anemia among adolescents in Denizli, Turkey," Iranian Journal of Pediatrics, vol. 22, no. 1, pp. 77-81, 2012.

[13] World Health Organization, Prevention of Iron Deficiency Anemia in Adolescents: A Role of Weekly Iron and Folic Acid Supplementation, World Health Organization, Geneva, Switzerland, 2011.

[14] M. A. Hafeez, H. M. Rafique, A. W. Shaikh, and Z. A. Laghari, "Prevalence of anaemia and its association with diet among the adolescent students of university of Sindh Jamshoro," Pakistan Journal of Medical and Health Sciences, vol. 10, no. 2, pp. 383-386, 2016.

[15] M. Mesías, I. Seiquer, and M. P. Navarro, "Iron nutrition in adolescence," Critical Reviews in Food Science and Nutrition, vol. 53, no. 11, pp. 1226-1237, 2013.

[16] R. C. De Andrade Cairo, L. Rodrigues Silva, N. Carneiro Bustani, and C. D. Ferreira Marques, "Iron deficiency anemia in adolescents; a literature review," Nutricion Hospitalaria, vol. 29, no. 6, pp. 1240-1249, 2014.

[17] M. Teni, S. Shiferaw, and F. Asefa, "Anemia and its relationship with academic performance among adolescent school girls in Kebena district, Southwest Ethiopia," Biotechnology and Health Sciences, vol. 4, no. 1, 2017.

[18] S. Osendarp and A. Eilander, "Iron deficiency and cognitive development," in Lifetime Nutritional Influences on Cognition, Behaviour and Psychiatric Illness, pp. 94-108, Elsevier, Amsterdam, Netherlands, 2011.

[19] G. Ayele and M. Bezatu, Prevalence of Anaemia and Associated Factors Among Adplescent Girls in Rural Schoolof Doba District, West Hararghe, Eastern Ethiopia, Harmaya University, Dire Dawa, Ethiopia, 2016.
[20] CSA, Ethiopia Demographic and Health Survey Key Indicators Report Central Statistics Agency Addis Ababa, Ethiopia, The, DHS Program ICF, Rockville, Maryland, USA, 2016.

[21] Government of the Federal Democratic Republic of Ethiopia, National Nutrition Programme, WHO, Geneva, Switzerland, 2015.

[22] https://en.wikipedia.org/wiki/Dila, Ethiopia.

[23] World Weather Online, Dilla Weather Averages, World Weather Online, Manchester, UK, 2020, https://www. worldweatheronline.com/dilla-weather-averages/et.aspx.

[24] M. F. Shaka and Y. A. Wondimagegne, "Anemia, a moderate public health concern among adolescents in South Ethiopia," PLoS One, vol. 13, no. 7, Article ID e0191467, 2018.

[25] M. Tesfaye, L. G. Bimerew, T. Yemane, and W. Adissu, "Anemia and iron deficiency among school adolescents: burden, severity, and determinant factors in Southwest Ethiopia," Adolescent Health, Medicine and Therapeutics, vol. 6, no. 1, p. 189, 2015.

[26] M. D. Onis, A. W. Onyango, E. Borghi, A. Siyam, C. Nishida, and J. Siekmann, "Development of a WHO growth reference for school-aged children and adolescents," Bulletin of the World Health Organization, vol. 85, pp. 660-667, 2007.

[27] F. Sanchis-Gomar, J. Cortell-Ballester, H. Pareja-Galeano, and G. Lippi, "Hemoglobin point-of-care testing: the HemoCue system," Journal of Laboratory Automation, vol. 18, no. 3, pp. 198-205, 2013.

[28] M. F. Olumakaiye, "Adolescent girls with low dietary diversity score are predisposed to iron deficiency in Southwestern Nigeria," Infant, Child, \& Adolescent Nutrition, vol. 5, no. 2, pp. 85-91, 2013.

[29] S. K. Soman, B. Areekal, A. J. Murali, and R. G. Varghese, "Adolescent anaemia its prevalence and determinants: a cross-sectional study from south Kerala, India," International Journal of Community Medicine and Public Health, vol. 4, no. 8, pp. 2750-2756, 2017.

[30] T. Premalatha, V. Srinivasan, P. Srijayanth, and J. S. Sundar, "Prevalence of anemia and its associated factors among adolescent school girls in Chennai, Tamil Nadu, India," Epidemiology, vol. 2, no. 118, pp. 1165-2161, 2012.

[31] D. I. Tayel and S. Ezzat, "Anemia and its associated factors among adolescents in Alexandria, Egypt," International Journal of Health Sciences and Research (IJHSR), vol. 5, pp. 260-271, 2015.

[32] B. Teucher, M. Olivares, and H. Cori, "Enhancers of iron absorption: ascorbic acid and other organic acids," International Journal for Vitamin and Nutrition, vol. 74, no. 6, pp. 403-419, 2004.

[33] P. J. Hotez, S. Brooker, J. M. Bethony, M. E. Bottazzi, A. Loukas, and S. Xiao, "Hookworm infection," New England Journal of Medicine, vol. 351, pp. 799-807, 2004.

[34] D. Nelima, "Prevalence and determinants of anaemia among adolescent girls in secondary schools in yala division Siaya district, Kenya," Universal Journal of Food and Nutrition Science, vol. 3, no. 1, pp. 1-9, 2015.

[35] A. Mulugeta, M. Gebre, M. Abdelkadir, A. G. Tsadik, and B. Stoecker, "Iron deficiency in adolescent school girls from Tigray, Northern Ethiopia," Federation of American Societies for Experimental Biology, vol. 24, no. S1, 2010. 